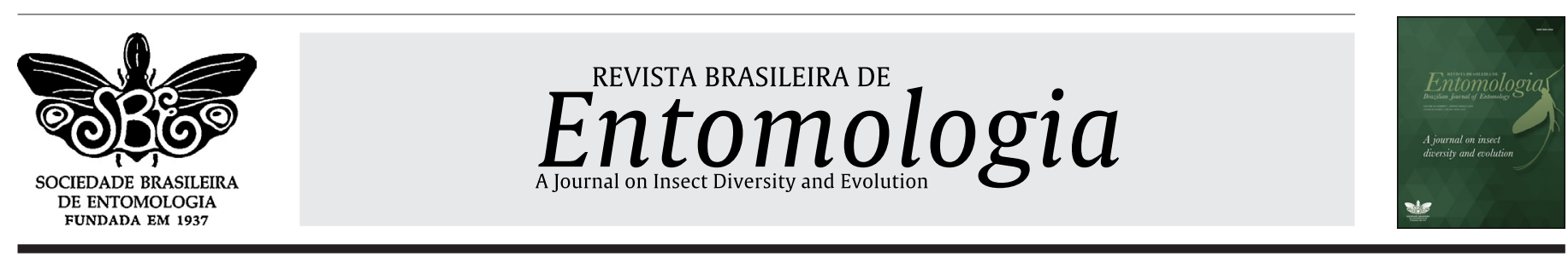

\title{
First record of Hirsutella saussurei in the Galápagos Islands and first evidence parasitizing the invasive paper wasp, Polistes versicolor
}

\author{
Óscar Molláa ${ }^{*}$ (i), Bhushan Shrestha ${ }^{2}$, Christian Sevilla ${ }^{3}$, Danny Rueda ${ }^{3}$, \\ Fernando Rivas ${ }^{1}$, Henri William Herrera ${ }^{1}$ \\ ${ }^{1}$ Escuela Superior Politécnica de Chimborazo, Facultad de Recursos Naturales, Departamento de Entomología, Riobamba, Ecuador \\ ${ }^{2}$ Catholic Kwandong University, International St. Mary's Hospital and College of Medicine, Biomedical Institute of Mycological \\ Resource, Translational Research Division, Incheon, Republic of Korea. \\ ${ }^{3}$ Dirección del Parque Nacional Galápagos, Departamento de Ecosistemas, Santa Cruz-Galápagos, Ecuador.
}

\section{A R T I C L E I N F O}

Article history:

Received 07 April 2020

Accepted 13 May 2020

Available online 29 June 2020

Associate Editor: Marcel Hermes

\section{Keywords:}

Hirsutella saussurei

Entomogenous fungus

Galápagos Islands

Polistini

Invasive species

\begin{abstract}
A B S T R A C T
In the present work we report the first occurrence of the entomogenous fungus Hirsutella saussurei, in the Galápagos Islands, and also the first evidence of this fungus parasitizing a new host: the invasive paper wasp Polistes versicolor. Some wasps parasitized by the fungus were found in Santa Cruz island in 2018 and 2019, while two new specimens were found in Floreana in 2019. Our data enlarge both the geographical distribution of the fungus and the host range. Even though $P$. versicolor is considered an important threat for the Galapagos endemic fauna, it is necessary a deep research to know if $H$. saussurei could be included under control programs of this invasive wasp.
\end{abstract}

Hirsutella (Ascomycota: Hypocreales) is a pathogenic genus of fungus that can infect different groups of insects and comprises a large number of species (Ferron, 1978). In the Galápagos Islands, Hirsutella spp. have been described infesting several groups of insects (Evans and Samson, 1982; Iturriaga, 2014). In the literature, Hirsutella saussurei (Cooke) Speare (Ascomycota: Hypocreales) has been recorded from several countries parasitizing both Polistes (Hymenoptera: Vespidae) and other vespid wasps (Vosseler, 1902; Speare, 1920; Petch, 1924, 1948; Mains, 1951; Tanada, 1956; Ulloa and Benavides, 1991; Tzean et al., 1997; Rose et al., 1999; Van Vooren and Audibert, 2005; Luangsaard et al., 2008; Montalva et al., 2017), although the Polistes hosts are only described in a few studies: Polistes americanus (Fabricius) (Cooke, 1892) latter considered as synonymous name of the species Polistes crinitus(Felton) (Carpenter, 1996), Polistes rubiginosus Latreille (Mains, 1951), Polistes annularis Linnaeus (Speare, 1920) and Polistes olivaceus DeGeer (Van Vooren and Audibert, 2005).

In 2018, we detected an entomogenous fungus parasitizing Polistes versicolor(Olivier) (Hymenoptera: Vespidae) on Santa Cruz (Galápagos
Islands, Ecuador) on two occasions. The first infected wasp was found on a coffee leaf Coffea arabica L. (Gentianales: Rubiaceae) in August (UTM 15 S 797829 9924188), and the second specimen was found on a corn plant Zea mays L. (Cyperales: Poaceae) in October(UTM 15 S 797670 9924352), both in an agricultural field at Bellavista on Santa Cruz. Both wasps had synnemata arising from various parts of the body (Fig. 1). The parasitized specimens were collected, and fungus was identified as H. saussurei. Some preparations of the hyphae and phialides of the fungus were deposited in the Entomological Collection of ESPOCH. The first diagnosis of $H$. saussurei was made by Cooke (1892) who identified the species under the provisional name of Isaria saussurei based on the Saussure's illustration (Saussure, 1858). Speare (1920) provided the first description of I. saussurei as Hirsutella saussurei. Our specimens were identified as H. saussurei, based on the morphology of the hyphae and phialides (Fig. 2), according to those described by Mains (1951). Hirsutella saussurei is characterized by synnemata aerial or procumbent and appressed to the substratum, arising from various parts of the body and appendages of the host (Fig. 1), slender,

\footnotetext{
* Corresponding author.

E-mail: oscar.molla@espoch.edu.ec(O. Mollá).
} 


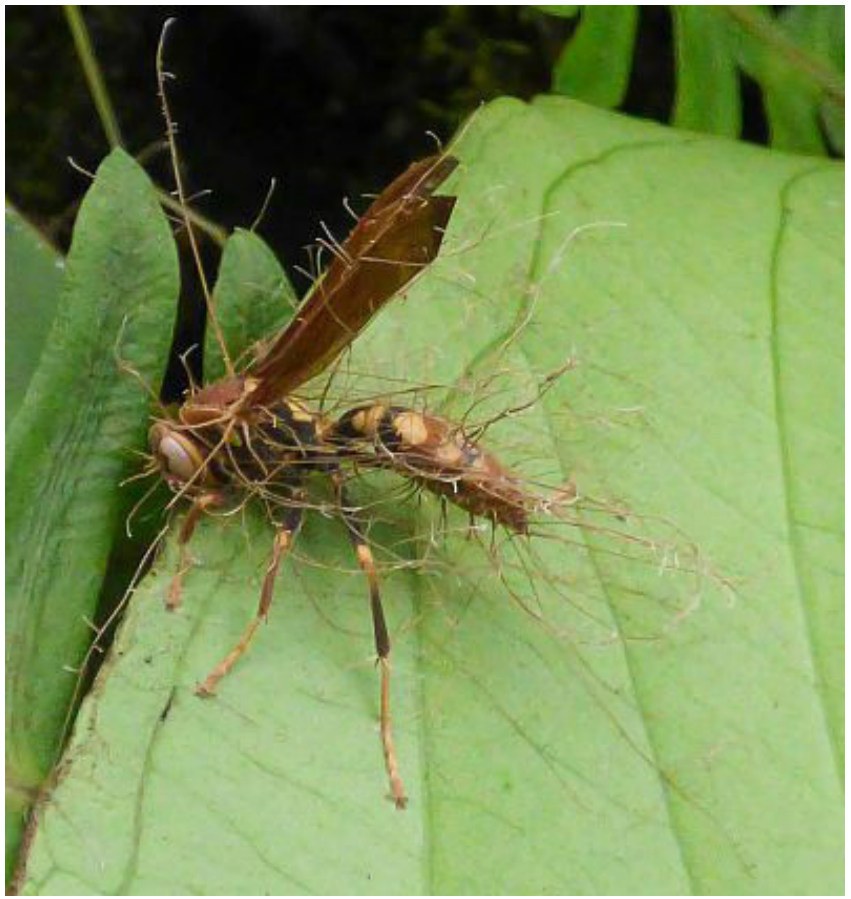

Figure 1. Synnemata of $H$. saussurei (Cooke) Speare (Ascomycota: Hypocreales) arising from host (P. versicolor(Olivier) (Hymenoptera: Vespidae)), picture was taken during a sampling at Cerro Luna, in Santa Cruz (Galápagos, Ecuador). It is possible to observe the hyphae of the fungi arising from some parts of the wasp body.

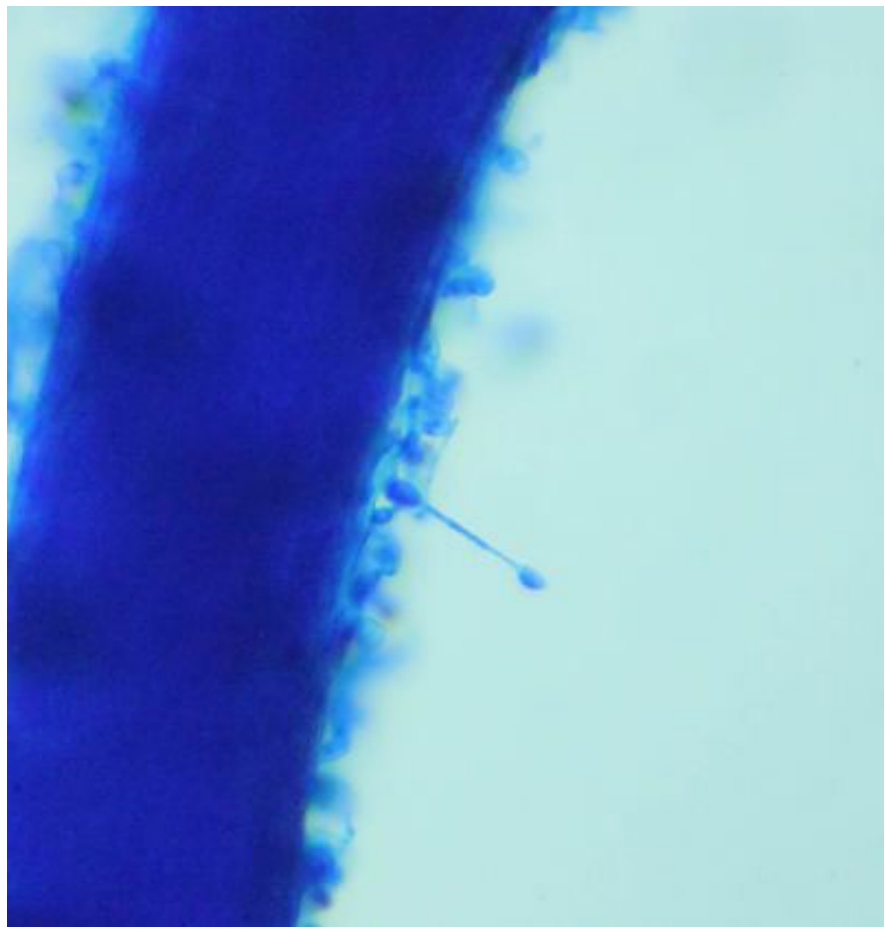

Figure 2. Phialidae (conidia attached at the apical part of the sterigmata) of $H$. saussure (Cooke) Speare (Ascomycota: Hypocreales) from our sample, photographed using a digital camera attached to a microscope $(1000 \mathrm{X})$ and previously dyed with blue of lactophenol.

terete, somewhat attenuated upward, very variable in length, 1-7 mm long. 0.1-0.3 mm thick, light brown, composed of closely compacted, parallel, longitudinal, and 2-4 $\mu$ wide hyphae; phialides scattered to moderately crowded, arising as lateral cells or buds from the outer hyphae of the synnema or as terminal cells of short lateral branches, the lower portions cylindrical, obovoid or ellipsoid, 7-16 × 3-6 $\mu$, attenuated above into slender sterigmata $10-40 \mu$ long (Fig. 2) (Mains,
1951). To our knowledge the two infested wasps constitute the first report of $H$. saussurei for the Galápagos Islands. This is also the first report of the fungus parasitizing a new host: $P$. versicolor.

In July 2019, after the identification of the fungus, we found five individuals of $P$. versicolor parasitized by $H$. saussurei at Cerro Media Luna (UTM 15S 797762 9926274), in the humid zone of Bellavista (Santa Cruz). Two additional individuals were found in the humid zone of Floreana (UTM 15S 7834889856168 ) suggesting that the fungus can spread to other islands.

All wasp specimens were found dead laying on a vegetable substrate. New studies described the ability of this fungus to manipulate their wasp host on different ways to place the host in a suitable location for the fungal development and dispersion (Somavilla et al., 2019). Sexual (Ophiocordyceps humbertii (Ascomycota: Hypocreales)) and asexual ( $H$. saussurei) stages of the fungus develop onto understory vegetation when nests are swarm-founding wasp species while only asexual stage of the fungus is developed in independent-founding wasp species (Somavilla et al., 2019).

The distribution of the paper wasp, $P$. versicolor, ranges from Costa Rica to Argentina (Richards, 1978). In the Galápagos Islands, $P$. versicolor was first recorded in 1988, probably introduced from a cargo-ship transporting fruits such as bananas (Abedrabbo, 1991). This wasp is highly invasive (Causton et al., 2006) and its predatory behavior has a negative impact on endemic species of the Galápagos Islands by preying on larvae of other insects (Parent, 2000). For a density of three nests per $100 \mathrm{~m}^{2}, P$. versicolor can prey upon $154.5 \mathrm{~g}$ of insects per hectare per day, mainly Lepidoptera larvae ( $46 \%$ of prey) (Parent, 2000). This preference for caterpillars was observed in other studies. In Brazil, Prezoto et al. (2006) observed that $95.4 \%$ of the prey of $P$. versicolor was Lepidoptera larvae. Since caterpillars are one of the most important resources for some species of Darwin's finches in the breeding season (Boag and Grant, 1984) and other insectivorous animals; $P$. versicolor has become a significant competitor of the native Galápagos fauna (Parent, 2000).

The negative impact of $P$. versicolor on the Galápagos Islands' biodiversity makes necessary the implementation of an urgent action plan to control its population. The use of pesticides could harm non-target organisms, both arthropods and vertebrates (Desneux et al., 2007; López et al., 2012), and the environment. Therefore, strong emphasis should be placed on implementing environmentally safe measures such as biological control.

Since the detection of $P$. versicolor in the Galápagos Archipelago, some natural enemies have been reported exploiting it as prey or host. Lasso (1997) found two species of Lepidopteran (Erechtias minuscula (Walsinghan) (Lepidoptera: Tineidae) and possibly Holocera sp. (Lepidoptera: Blastobasidae)) parasitizing nests of the wasp. In addition, Parent (2000) reported the presence of the predatory moth Taygete sphecophila (Meyrick) (Lepidoptera: Autostichidae) in some nests of $P$. versicolor, the highest percentage of predation was found in the humid area of Floreana, and it was low (only $58.7 \%$ of sampled nests showed evidence of predation by the moth). All these natural enemies contribute to reduce $P$. versicolor populations, but due to the high population of $P$. versicolor observed their action has had little impact. Therefore, searching for effective additional natural enemies of this invasive wasp has become an imperative task to reduce its population and its negative impact in the islands.

Although $H$. saussurei has been reported mainly infecting vespids (both Polistes spp. and Vespula spp.), and could be good candidate to include in the Integrated Pest Management Program of the invasive paper wasp P. versicolor in the Galápagos Islands, further work is needed to ascertain whether this fungus could have negative impact on endemic fauna of the Archipelago, before making a conclusion. 


\section{Acknowledgements}

We thank the Galápagos National Park Directorate (GNPD) for providing research authorizations and Alvaro Mauricio Rivera (ESPOCH) for assistance in the laboratory. Thanks also to Normania Coello, Angeles Prado and Sandra García from the Ministerio de Agricultura y Ganadería (MAG-Galápagos) who donated material of Polistes versicolor collected from farms. Bhushan Shrestha acknowledges the support of Bio-industry Technology Development Program (316025-05) of IPET (Korea Institute of Planning and Evaluation for Technology in Food, Agriculture, Forestry and Fisheries) of Ministry for Food, Agriculture, Forestry and Fisheries, Republic of Korea. Dr. Jacques Brodeur (Université de Montréal) and Dr. Bradley J. Sinclair (Canadian Food Inspection Agency) provided helpful comments on a previous draft of the manuscript. This research was supported by the Vice-Rectorate for Research and the Research Institute of Escuela Superior Politécnica de Chimborazo (ESPOCH).

\section{Conflicts of interest}

The authors declare there is no conflicts of interest.

\section{Author contribution statement}

All authors contributed to the study conception and design. Material preparation, data collection and analysis were performed by Óscar Mollá. First identification of the fungus was made by Óscar Mollá and confirmed by Bhushan Shrestha. The first draft of the manuscript was written by Óscar Mollá and all authors commented on previous versions of the manuscript. All authors read and approved the final manuscript.

\section{References}

Abedrabbo, S., 1991. Nueva avispa introducida en las islas. Carta Informativa. 31 (4).

Boag, P. T., Grant, P. R., 1984. Darwin's finches (Geospiza) on Isla Daphne Major, Galapagos: breeding and feeding ecology in a climatically variable environment. Ecol. Monogr. 54 (4), 463-489. https://doi. org/10.2307/1942596.

Carpenter, J. M., 1996. Distributional checklist of species of the genus Polistes (Hymenoptera, Vespidae, Polistinae, Polistini). Am. Mus. Novit. 3188, 1-39.

Causton, C. E., Peck, S. B., Sinclair, B. J., Roque-Albelo, L., Hodgson, C. J., Landry, B., 2006. Alien insects: threats and implications for conservation of Galápagos Islands. Ann. Entomol. Soc. Am. 99(1), 121-143. https://doi. org/10.1603/0013-8746(2006)099[0121:AITAIF]2.0.CO;2.

Cooke, M.C., 1892. Vegetable Wasps and Plant Worms: a Popular History of Entomogenous Fungi, or Fungi Parasitic Upon Insects. Society for Promoting Christian Knowledge, London.

Desneux, N., Decourtye, A., Delpuech, J. M., 2007. The sublethal effects of pesticides on beneficial arthropods. Annu. Rev. Entomol. 52, 81-106. https://doi.org/10.1146/annurev.ento.52.110405.091440.

Evans, H. C., Samson, R. A., 1982. Entomogenous fungi from the Galápagos Islands. Can.J. Bot. 60 (11), 2325-2333. https://doi.org/10.1139/b82-284.

Ferron, P., 1978. Biological control of insect pests by entomogenous fungi. Annu. Rev. Entomol.23(1), 409-442. https://doi.org/10.1146/annurev. en.23.010178.002205.

Iturriaga, T. 2014. CDF Checklist of Galapagos Sac fungi: Mildews, Molds, Morels. Charles Darwin Foundation Galapagos Species Checklist. Charles Darwin Foundation, Puerto Ayora, Galapagos. Available in: http://www.darwinfoundation.org/datazone/checklists/true-fungi/ ascomycota/ (accessed 22 May 2019).
Lasso, T. L., 1997. Ecología e impacto de la avispa introducida (Polistes versicolor, Vespidae-Hymenoptera) en las Islas Floreana y Santa Cruz, Galápagos Ecuador. Bachelor of Science Thesis, Universidad Central del Ecuador.

López, S. L., Aiassa, D., Benítez-Leite, S., Lajmanovich, R., Manas, F., Poletta, G., Sanchéz, N., Simoniello, M. F., Carrasco, A. E., 2012. Pesticides used in South American GMO-based agriculture: A review of their effects on humans and animal models. Adv. Mol. Toxicol. 6, 41-75. https:// doi.org/10.1016/B978-0-444-59389-4.00002-1.

Luangsa-ard, J.J., Tasanathai, K., Mongkolsamrit, S., Hywel-Jones, N. L., 2008. Atlas of Invertebrate-pathogenic Fungi of Thailand. Vol. 2. National Center for Genetic Engineering and Biotechnology, National Science and Technology Development Agency, Bangkok.

Mains, E. B., 1951. Entomogenous species of Hirsutella, Tilachlidium and Synnematium. Mycologia 43 (6), 691-718. https://doi.org/10.1080/0 0275514.1951.12024164.

Montalva, C., Rojas, E., Valenzuela, E., Humber, R. A., 2017. Hirsutella sp. (Hypocreales: Ophiocordycipitaceae) affecting the invasive social wasp Vespula vulgaris (Hymenoptera: Vespidae) in southern Chile. Fla. Entomol. 100 (3), 663-666. https://doi.org/10.1653/024.100.0327.

Parent, C., 2000. Life-cycle and Ecological Impact of Polistes versicolor versicolor(Olivier)(Hymenoptera: Vespidae), an Introduced Predatory Wasp on the Galapagos Islands, Ecuador. Master of Science Thesis, Carleton University.

Petch, T., 1924. Studies in entomogenous fungi: IV. Some Ceylon Cordyceps. Trans. Br. Mycol. Soc. 10 (1-2), 28-45. https://doi.org/10.1016/S00071536(24)80005-0.

Petch, T., 1948. A revised list of British entomogenous fungi. Trans. Br. Mycol. Soc. 31 (3-4), 286-304. https://doi.org/10.1016/S0007-1536(48)80014-8.

Prezoto, F., Santos-Prezoto, H. H., Machado, V. L., Zanuncio, J. C., 2006. Prey captured and used in Polistes versicolor (Olivier) (Hymenoptera: Vespidae) nourishment. Neotrop. Entomol. 35 (5), 707-709. https:// doi.org/10.1590/S1519-566X2006000500021.

Richards, O.W., 1978. Social Wasps of the Americas Excluding the Vespinae. Trustees of the British Museum (Natural History), London, No. 785, vii +580 pp. +4 pls.

Rose, E. A. F., Harris, R. A., Glare, T. R., 1999. Possible pathogens of social wasps (Hymenoptera: Vespidae) and their potential as biological control agents. N. Z. J. Zool. 26 (3), 179-190. https://doi.org/10.1080/ 03014223.1999.9518188.

Saussure, H., 1858. Des maladies des guepes. In: Saussure, H. Monographic des Guepes Sociales ou de la Tribu Vespiens 2. Vol. 152-164. Masson, Paris, Chapitre IX.

Somavilla, A., Barbosa, B. C., Prezoto, F., Oliveira, M. L., 2019. Infection and behavior manipulation of social wasps (Vespidae: Polistinae) by Ophiocordyceps humbertii in Neotropical forests: new records of wasp-zombification by a fungus. Stud. Neotrop. Fauna Environ. 54, 1-6. https://doi.org/10.1080/01650521.2019.1691908.

Speare, A. T., 1920. On certain entomogenous fungi. Mycologia 12 (2), $62-$ 76. https://doi.org/10.1080/00275514.1920.12016820.

Tanada, Y., 1956. An annotated list of infectious diseases of insects in Hawaii. Part II. Proc. Hawaii. Entomol. Soc. 16, 149-155. https://doi. org/10.3733/hilg.v26n14p597.

Tzean, S. S., Hsieh, L. S., Wu, W. J., 1997. Atlas of Entomopathogenic Fungi from Taiwan. Vol. 7. Council of Agriculture, Taiwan, 214 pp.

Ulloa, M., Benavides, C., 1991. Nota sobre Hirsutella saussurei, un Hifomicete patógeno de avispas sociales. Sci. Fungorum 3 (7), 175-178. https:// doi.org/10.33885/sf.1991.3.783.

Van Vooren, N., Audibert, C., 2005. Révision du complexe «Cordyceps sphecocephala». 1re partie: les guêpes végétales. Publ. Soc. Linneenne Lyon 74 (7), 221-254. https://doi.org/10.3406/linly.2005.13604.

Vosseler, J., 1902. Ueber einige Insektenpilze. Jahresh. Ver. vaterl. Naturkd. Wb. 58, 380-388. 